\title{
ANALISA KELAYAKAN USAHATANI JAGUNG DI KABUPATEN CIAMIS
}

\author{
Oleh \\ AI HUSNUL KHOTIMAH \\ Fakultas Pertanian Universitas Galuh Ciamis \\ e-mail: khaihusnul@gmail.com
}

\begin{abstract}
Abstrak
Penelitian ini bertujuan untuk mengetahui: (1) Besarnya biaya dan penerimaan pada usahatani jagung di Kabupaten Ciamis (2) R/C ratio pada usahatani jagung. Metode yang digunakan dalam penelitian ini adalah metode survai dengan mengambil kasus pada komoditi jagung di Kabupaten Ciamis. Teknik penarikan sampel dilaksanakan menggunakan two stage cluster random sampling untuk sampel area dan strata simple random sampling untuk sampel petani. Data yang diperoleh dianalisa secara deskriptif. Usahatani jagung dianalisis dengan analisis biaya, pendapatan dan R/C. Hasil penelitian menunjukkan bahwa usahatani jagung di Kabupaten Ciamis sudah mulai pada usahatani komersial, dengan teknik budidaya yang masih konvensional, yang pelaksanaannya dipadukan dengan budidaya ternak. R/C yang didapat sebesar 2,22 menunjukkan bahwa usahatani jagung di Kabupaten Ciamis menguntungkan.
\end{abstract}

Kata kunci: usahatani, jagung,biaya, penerimaan, R/C

\section{PENDAHULUAN}

Perekonomian Indonesia telah dan sedang mengalami proses transformasi struktural yang dicirikan oleh : (1) peran relatif sektor pertanian dan sumbangannya terhadap PDB dan penyerapan tenaga kerja semakin menurun, (2) pangsa ekspor bahan setengah jadi dan jadi makin besar, (3) keterkaitan antar berbagai sektor ekonomi semakin tinggi, (4) daerah pedesaan semakin terbuka, baik berupa hubungan antar desa dan kota maupun berupa arus informasi sehingga pola pikir petani semakin kritis dan rasional dan (5) terjadinya pola usahatani dari orientasi peningkatan produksi semata-mata kepada orientasi pemanfaatan sumber daya yang optimal dalam rangka meraih nilai tambah hasil produksi pertanian yang lebih besar (Baharsyah, 1996).

Berbagai komitmen yang telah disepakati oleh Indonesia dibidang ekonomi termasuk sektor pertanian merupakan bagian yang tak terpisahkan dalam era globalisasi ekonomi. Liberalisasi ekonomi mendorong iklim ekonomi internasional sedemikian rupa, sehingga mekanisme pasar bekerja dengan hambatan yang minimum. Persaingan dalam perdagangan internasional menjadi makin terbuka dan transparan, dalam pelaksanaannya liberalisasi perdagangan internasional merupakan proses tawar menawar antar negara atau kelompok negara didalam kesepakatan yang mengikat atas dasar kepentingan nasional masing-masing.
Keterpaduan antara perekonomian Indonesia dan perdagangan internasional "International Trade" semakin erat. Kebijakan terbuka sejak tahun 1980'an "outward looking strategi" ternyata menghadapi resiko "rawan" terhadap tingkat harga dunia dan fluktuasi ekonomi dari negara-negara lain. Untuk mengantisipasi keadaan demikian, maka peningkatan efisiensi disektor pertanian sejak proses produksi usahatani sampai agroindustri dihilirnya merupakan suatu keharusan untuk dapat mampu bersaing di era globalisasi (Kasryno dan Suryana, 1992).

Menghadapi perubahan lingkungan strategis tersebut serta memanfaatkan peluang yang ditimbulkannya, maka pembangunan pertanian harus lebih difokuskan pada komoditas unggulan yang dapat bersaing di pasar domestik maupun internasional. Kondisi seperti ini merupakan dasar yang kuat untuk mempercepat reorientasi arah pembangunan sektor pertanian dari orientasi semata-mata peningkatan produksi kepertanian modern yang berorientasi agribisnis (Faisal Kasryno, 1996).

Pengembangan pertanian sekarang ini tidak hanya berorientasi pada satu macam komoditas strategis tetapi mencapai juga alternatif komoditas yang dapat menyangga kebijakan swasembada pangan nasionl. Salah satu komoditas yang dikembangkan adalah palawija. Pengembangan palawija dilaksanakan secara serasi, terpadu dan merata dengan tetap memelihara kelestarian sumberdaya alam dan 


\section{MIMBAR \\ Agribisnis \\ ISSN 2460-4321}

Volume 1・ Nomor 2・ Januari 2016

lingkungan untuk mencapai pertanian yang tangguh sehingga dapat memenuhi kebutuhan gizi masyarakat dan meningkatkan pendapatan petani.

Palawija bukan lagi hanya sebagai pelengkap, tetapi sudah menjadi bagian integral dari suatu pola tanam dan pola usahatani. Untuk memenuhi konsumsi nasional, palawija khususnya kedelai, jagung dan kacang tanah, berbagai komponen teknologi yang menyangga produktivitas tanaman diperbaiki dan pola tanam dirancang berdasarkan ekoregional agar lahan dapat dimanfaatkan semaksimal mungkin.

Jagung (Zea mays) merupakan salah satu jenis tanaman pangan yang mendapat prioritas untuk dikembangkan karena kedudukannya disamping sebagai bahan baku utama industri pakan ternak dan industri lainnya, sehingga mempunyai potensi yang besar untuk meningkatkan pendapatan petani, serta merupakan komoditas penting dalam upaya diversifikasi pangan. Selain itu juga jagung merupakan sumber utama karbohidrat dan protein. Selengkapnya mengenai kandungan gizi pada jagung dapat dilihat pada Tabel 1 .

Tabel 1. Kandungan Nutrisi atau Zat Makanan pada Biji Jagung per 100 gram

\begin{tabular}{|c|l|c|}
\hline No & \multicolumn{1}{|c|}{ Bagian } & Jumlah \% \\
\hline 1 & Air & 11,10 \\
2 & Putih telur & 9,09 \\
3 & Lemak & 4,72 \\
4 & Karbohidrat & 71,35 \\
5 & Serat kasar & 2,04 \\
6 & Abu Jumlah & 1,70 \\
\hline \multicolumn{2}{|c|}{ Jum } & 100,00 \\
\hline
\end{tabular}

Sumber : AAK, 1993

Jagung merupakan komoditas palawija utama di Indonesia ditinjau dari aspek pengusahaan dan penggunaan hasilnya, yaitu sebagai bahan baku pangan dan pakan. Kebutuhan jagung terus meningkat seiring dengan meningkatnya permintaan bahan baku pakan. Komposisi bahan baku pakan ternak unggas membutuhkan jagung sekitar 50 persen dari total bahan yang digunakan (Sarasutha, 2002).

Usaha budidaya tanaman jagung mempunyai arti ekonomi yang strategis, karena jagung disamping dapat digunakan sebagai makanan pokok kedua setelah padi (sekitar 70 persen dari produksi jagung digunakan sebagai konsumsi), juga dapat dipergunakan sebagai suplemen makanan ternak dan bahan baku industri, sehingga mempunyai prospek pemasaran yang cukup cerah (Samuel, Musyafak dan Sahari, 1999).

Usahatani jagung di Kabupaten Ciamis tersebar di 28 kecamatan dengan luas lahan 5.735 hektar dan produksi yang dihasilkan sebanyak 24.640,50 ton dan rata-rata produktivitas usahatani jagung di Kabupaten Ciamis sebesar 4,30 ton per hektar. Selengkapnya mengenai luas lahan, produksi dan produktivitas usahatani jagung di Kabupaten Ciamis tahun 2006 dapat dilihat pada Tabel 2.

Tabel 2. Luas lahan, Produksi dan Rata-rata

Produktivitas Usahatani Jagung per Kecamatan di Kabupaten Ciamis Tahun 2006

\begin{tabular}{|l|l|c|c|c|}
\hline No & Kecamatan & $\begin{array}{c}\text { Luas } \\
\text { Lahan } \\
\text { (Ha) }\end{array}$ & $\begin{array}{c}\text { Produksi } \\
\text { (Ton) }\end{array}$ & $\begin{array}{c}\text { Produktiv } \\
\text { itas } \\
\text { (Ton/Ha) }\end{array}$ \\
\hline 1. & Cijulang & 285 & $1.320,00$ & 4,63 \\
2. & Cigugur & 469 & $1.852,00$ & 3,95 \\
3. & Parigi & 417 & $1.970,00$ & 4,72 \\
4. & Pangandaran & 113 & 484,00 & 4,28 \\
5. & Kalipucang & 240 & $1.400,00$ & 5,83 \\
6. & Padaherang & 235 & $1.421,00$ & 6,05 \\
7. & Banjarsari & 251 & $1.982,00$ & 7,90 \\
8. & Langkaplancar & 463 & $1.111,00$ & 4,20 \\
9. & Pamarican & 217 & 929,00 & 4,28 \\
10. & Cimaragas & 15 & 59,00 & 3,90 \\
11. & Cisaga & 118 & 521,00 & 4,42 \\
12. & Cijeungjing & 173 & 651,00 & 3,76 \\
13. & Ciamis & 55 & 207,00 & 3,76 \\
14. & Cipaku & 99 & 375,00 & 3,79 \\
15. & Cikoneng & 118 & 464,00 & 3,93 \\
16. & Cihaurbeuti & 120 & 464,00 & 3,88 \\
17. & Panumbangan & 175 & 680,00 & 3,89 \\
18. & Panjalu & 236 & 858,00 & 2,64 \\
19. & Kawali & 68 & 249,00 & 3,66 \\
20. & Panawangan & 110 & 419,00 & 3,81 \\
21. & Rajadesa & 441 & $1.984,50$ & 4,50 \\
22. & Rancah & 267 & $1.038,00$ & 3,89 \\
23. & Cimerak & 525 & $2.000,00$ & 3,81 \\
24. & Sukadana & 89 & 349,00 & 3,92 \\
25. & Jatinagara & 110 & 479,00 & 4,35 \\
26. & Tambaksari & 163 & 651,00 & 3,99 \\
27. & Cidolog & 43 & 170,00 & 3,95 \\
28. & Sidamulih & 120 & 551,00 & 4,59 \\
\hline Jumlah & 5.735 & $24.640,50$ & \\
\hline Rata rata & 204,82 & 880,02 & 4,30 \\
\hline Sumb & Ser Dinas Pertan \\
\hline
\end{tabular}

Sumber : Dinas Pertanian Kabupaten Ciamis, 2006

Tabel 2 menunjukkan bahwa lahan yang digunakan untuk usahatani jagung di Kecamatan Padaherang seluas 235 hektar 


\section{Analisa Kelayakan Usahatani Jagung \\ di Kabupaten Ciamis}

AI HUSNUL KHOTIMAH

dengan produksi yang dihasilkan sebanyak 1.421 ton dan produktivitasnya 6,05 ton per hektar. Kecamatan Padaherang merupakan salah satu sentra pengembangan jagung di Kabupaten Ciamis, dan lahan yang potensial untuk budidaya jagung di Kecamatan Padaherang belum sepenuhnya diusahakan, dengan demikian masih terdapat peluang dalam pengembangan jagung di Kecamatan Padaherang.

Sementara berdasarkan Tabel 2 juga bahwa lahan yang digunakan untuk usahatani jagung di Kecamatan Panumbangan seluas 175 hektar, menghasilkan produksi sebanyak 680,00 ton dan produktivitas 3,89 ton per hektar. Di Kecamatan Panumbangan ini terdapat industri pakan ternak Tanjung Mulya, dimana sebagian besar produksi jagung di Kabupaten Ciamis dipergunakan sebagai bahan baku utama pakan ternak.

Tabel 2 juga menunjukkan bahwa Kecamatan Panjalu memiliki lahan usahatani jagung seluas 236 hektar dengan produksi sebesar 858ton, dan rata-rata produktivitas sebesar 2,64 ton per hektar Sedangkan Kecamatan Rajadesa memiliki lahan usahatani untuk jagung seluas 441 hektar dengan produksi sebesar $1.984,50$ ton dan rata-rata produktivitas sebesar 4,50 ton per hektar. Kecamatan Rajadesa dan Kecamatan Panjalu ini merupakan Kecamatan yang dipilih untuk pengembangan komoditas jagung melalui Program Pengembangan Agribisnis (PPA) yang dilaksanakan mulai tahun 2003. Terpilihnya kedua kecamatan tersebut dalam pelaksanaan PPA ini disebabkan adanya potensi lahan baik lahan darat maupun sawah yang cukup luas serta kebiasaan petani menanam jagung secara kontinu yang usahataninya dipadukan dengan peternakan.

Penanganan pengembangan komoditi pertanian yang terputus-putus, misalnya pengembangan komoditi jagung yang belum diimbangi dengan kegiatan pengolahan dan pemasaran (ekspor) yang baik seringkali menyebabkan kelebihan produksi, sehingga harga produk berfluktuasi secara tajam. Sebaliknya ditemui pula adanya pabrik pengolahan hasil pertanian yang kekurangan bahan baku yang cukup dan kontinu.

Sejauh ini pemasaran merupakan subsistem terlemah dari sistem agribisnis. Salahsatu masalah yang dihadapi dalam pemasaran hasil pertanian adalah adanya perbedaan harga yang cukup besar antara petani produsen dengan harga ditingkat konsumen. Hal ini mungkin disebabkan oleh adanya biaya tataniaga yang tinggi. Tingginya biaya tataniaga biasanya oleh lembaga tataniaga dilemparkan kepada pihak produsen atau konsumen, karena mereka tidak mau rugi, misalnya dengan cara meningkatkan harga konsumen atau dengan cara menekan harga ditingkat petani. Usaha yang mungkin dapat ditempuh adalah dengan menekan biaya pemasaran atau dengan memperkecil perbedaan harga jual petani dengan harga beli konsumen atau dengan istilah memperkecil marjin pemasaran. Untuk memperkecil marjin pemasaran tersebut salah satunya dengan mengefisienkan saluran pemasaran.

Pihak-pihak yang terlibat dalam pemasaran maupun agribisnis pada umumnya, perlu memiliki kepedulian "commitmen" untuk membuat jalinan yang saling menguntungkan "mutual profit" termasuk petani didalamnya. Bila jalinan semacam itu dapat diwujudkan tidak mustahil agribisnis dapat berperan sebagai sistem yang mampu membuat perubahan "leading change agent" yang berdampak positif bagi perkembangan masyarakat tani secara menyeluruh (Williams and Karen dalam Steidelmeir,1987). Namun sebaliknya bila masing-masing lembaga yang terlibat berjalan sendiri-sendiri tanpa jalinan "inward-looking" dan "dispersal" maka akan timbul inefisiensi dan meningkatkan biaya pemasaran.

Kelemahan kultural yang masih melekat pada aparat kelembagaan maupun masyarakat tani menyebabkan imbang-tukar "term of trade" antara hasil pertanian dengan komoditas non pertanian semakin menjadi tak berimbang dan kenyataan ini mengurangi insentif pada petani untuk menghasilkan komoditas pertanian yang berkualitas, selain mengakibatkan biaya intervensi pasar yang tinggi juga menciptakan berbagai distorsi serta tidak berfungsinya jaringan pemasaran yang dapat memperlancar arus barang, untuk itu diperlukan reorientasi kebijakan.

Penelitian ini dilaksanakan dengan tujuan untuk mengetahui :

1) Besarnya biaya dan penerimaan dari usahatani jagung yang dilaksanakan oleh para petani. 


\section{AIMBAR \\ Agribisnis \\ ISSN 2460-4321}

Volume 1 • Nomor 2 • Januari 2016

2) Layak tidaknya usahatani jagung yang dilaksanakan oleh para petani.

\section{KAJIAN PUSTAKA}

Jagung merupakan tumbuhan berbiji tunggal (Monocotyedonate) dari famili padipadian ( Gramineae), oleh karena itu dilihat secara keseluruhan tanaman jagung akan mempunyai tanda-tanda sebagai berikut (Sarasutha, 2002):

1) Akarnya merupakan akar serabut

2) Batangnya kelihatan nyata beruas-ruas

3) Bijinya berkeping satu

4) Bunganya tersusun dalam karangan berbeda Menurut Dinas Pertanian tanaman pangan

Provinsi Jawa Barat (2004), keberhasilan bercocok tanam sangat di pengaruhi oleh tehnik budidaya yang dilakukan, artinya walaupun semaksimal mungkin sarana produksi terpenuhi tanpa di dukung oleh tehnik budidaya yang baik seperti halnya mengenai syarat tumbuh, benih, pemupukan, maka sangat kecil kemungkinan usaha tani tersebut berhasil. Oleh sebab itu Dinas Pertanian Tanaman Pangan Provinsi Jawa Barat (2004) merekomendasikan tehnik budidaya tanama jagung sebagai berikut :

1) Syarat tumbuh tanaman jagung : tanaman jagung dapat tumbuh hampir di semua macam tanah, tapi tanah yang dikehendaki adalah tanah gembur, subur, dan berdrainase baik dengan keasaman tanah (ph) 5,6 sampai 7,2. Pada tanah-tanah yang masam atau ph kurang dari 5,6 maka diperlukan pengapuran.

2) Varietas dan benih: varietas yang dianjurkan oleh Dinas Pertanian Tanaman Pangan Provinsi Jawa Barat (2004) adalah komposit dan hibrida. Benih jagung komposit adalah jagung bersari bebas, sehingga penyerbukan tetangga maupun penyerbukan sendiri sangat mungkin terjadi, sedangkan jagung hibrida adalah varietas jagung yang di hasilkan dari persilangan bibit unggul, sehingga daya hasil jagung hibrida lebih besar dari jagung komposit dan jagung lokal. Kebutuhan benih 20 sampai 40 kilogram per hektar tergantung dari jarak tanah yang digunakan.

3) Persiapan tanam: pada sawah irigasi sebaiknya ditanam pada musim kemarau. Pada sawah tadah hujan sebaiknya ditanam pada akhir musim hujan dan pada lahan darat sebaiknya ditanam pada awal musim hujan. Tanah diolah dalam kondisi lembab (tidak terlalu basah) tanah yang kurang gembur di bajak atau dicangkul dan diratakan. Penentuan jarak tanam hendaknya disesuaikan dengan umur jagung. Untuk jagung yang berumur lebih dari 100 hari hendaknya menggunakan jarak tanam $100 \times 40 \mathrm{~cm}$ dan setiap lubang berisi 2 tanaman, untuk jagung yang berumur 80 sampai 100 hari hendaknya menggunakan jarak tanam $75 \times 25 \mathrm{~cm}$ dan setiap lubang berisi 1 tanaman.

4) Penanaman: pada saat tanam sebaiknya tanah dalam keadaan lembab, bila kering diairi terlebih dahulu kecuali bila diduga 1 sampai 2 hari akan turun hujan.

5) Penyulaman dan penjarangan: penyulaman bertujuan untuk mengganti benih yang tidak tumbuh dan di lakukan pada umur 7 sampai 10 hari setelah tanam. Sedangkan penjarangan dapat menentukan jumlah tanaman per lubang tanam sesuai dengan yang dikehendaki.

6) Penyiangan dan pembumbunan: penyiangan bertujuan untuk membersihkan lahan dari tanaman penganggu (gulma) dan dapat dilakukan 15 hari setelah tanam. Sedangkan pembumbunan bertujuan untuk memperkokoh posisi batang agar tidak rebah, menutup akar yang bermunculan diatas permukaan tanah, serta dapat dilakukan bersamaan dengan pemupukan susulan, yaitu 4 sampai 5 minggu setelah tanam.

7) Pemupukan: aplikasi pemupukan yang direkomendasikan adalah pada saat tanam $100 \%$ SP-36 serta $35 \% \mathrm{KCl}$ dan urea, selebihnya dapat dilakukan pada saat tanaman berumur 4 sampai 5 minggu.

8) Pengairan: pada awal pertumbuhan kebutuhan airnya tidak terlalu tinggi dibandingkan dengan waktu berbunga yang membutuhkan air yang banyak. Pada waktu berbunga, waktu hujan yang pendek di selingi dengan cuca yang cerah akan lebih baik dari pada hujan terus menerus.

9) Pengendalian OPT (Organisme Pengganggu Tanaman) pengendalian hama secara terpadu (THT) merupakan cara pengendalian hama yang diterapkan 


\section{Analisa Kelayakan Usahatani Jagung \\ di Kabupaten Ciamis}

AI HUSNUL KHOTIMAH

dengan tujuan agar faktor pengendali alami seperti iklim, musuh alami, dan kompetitor dapat bekerja secara optimal.

10) Pemungutan hasil atau panen. Jagung dipungut pada waktu masih muda karena untuk berbagai kebutuhan, misalnya untuk jagung rebus, untuk jagung bakar, untuk sayur dan lain-lain. Jagung dipungut apabila sudah tua, dengan berbagai keperluan baik untuk makanan maupun untuk pakan ternak.

Mubyarto (1989) berpendapat bahwa usaha tani adalah himpunan dari sumber-sumber alam yang terdapat di tempat itu yang di perlukan untuk produksi pertanian seperti tanah dan air, perbaikan-perbaikan yang telah dilakukan atas tanah itu, sinar matahari, bangunan-bangunan yang di dirikan di atas tanah dan sebagainya. Suatu proses produksi yang di jalankan sebagai suatu usaha komersial memerlukan faktor produksi yang menentukan dan menunjang suatu keberhasilan produksi. Teken dan Asnawi (1985) menyatakan, bahwa produksi dapat mempunyai dua arti, teknis atau arti sempit dan arti ekonomis atau arti luas. Dalam pengertian teknis, produksi berarti proses menjadikan barang atau zat dan tenaga yang sudah ada. Sedangkan dalam arti ekonomis, produksi berarti proses menimbulkan guna atau menambah guna yang ada.

Biaya adalah pengorbanan sumber ekonomi, yang di ukur dalam satuan uang yang telah terjadi atau kemungkinan akan terjadi untuk mencapai suatu tujuan tertentu (Mulyadi, 1986). Biaya dapat digolongkan menjadi biaya variabel, biaya tetap, total biaya dan biaya ratarata (Hernanto, 1991).

Perhitungan penerimaan dan biaya yang dikeluarkan dalam proses produksi dilakukan setelah proses produksi selesai. Penerimaan dari usaha tani jagung adalah produksi jagung yang dihasilkan dikalikan harga produk. Hal ini sesuai dengan pendapat Soekartawi (1993), bahwa penerimaan usaha tani di depinisikan sebagai nilai produk total usaha tani dalam jangka waktu tertentu, baik yang di jual maupun yang tidak di jual dan di nilai dalam harga pasar setempat. Selisih antara penerimaan usaha tani dengan pengeluaran total usaha tani, disebut pendapatan usaha tani.

Abas Tjakrawiralaksana (1983), menyatakan bahwa untuk mengetahui tingkat kelayakan suatu cabang usaha tani, salah satunya dapat dilihat dengan analisis imbangan antara penerimaan dengan biaya produksi atau revenue cost ratio $(\mathrm{R} / \mathrm{C})$.

1) Apabila nilai $R / C$ lebih besar dari satu, maka usaha tani tersebut menguntungkan dan layak untuk diusahakan.

2) Apabila nilai $R / C$ sama dengan satu, maka usaha tani tersebut tidak memperoleh keuntungan dan kerugian (impass).

3) Apabila nila $R / C$ kurang dari satu, maka usaha tani tersebut mengalami kerugian dan tidak layak diusahakan.

\section{METODE PENELITIAN}

Metode yang digunakan dalam penelitian ini adalah metode survey, karena data yang dikumpulkan dibatasi dari sampel untuk mewakili seluruh populasi. Penelitian survey adalah penelitian yang mengambil sampel dari satu populasi dan menggunakan kuesioner sebagai alat pengambilan data yang pokok.

Adapun penarikan sampel yang digunakan dalam penelitian ini adalah dengan menggunakan two stage claster random sampling untuk sampel petani sebagai berikut:

1. Sampel daerah (areal sample)

Kecamatan Panjalu, Panumbangan, Rajadesa dan Padaherang dipilih dengan pertimbangan bahwa kecamatan tersebut merupakan kecamatan yang dipilih untuk pengembangan komoditas jagung melalui program pengembangan agribisnis (PPA) yang dilaksanakan dalam tahun 2003. Desa Sukanegara dipilih secara sengaja untuk mewakili Kecamatan Padaherang. Desa Kertamandala dipilih secara sengaja untuk mewakili Kecamatan Panjalu, Desa Tanjungjaya dipilih secara sengaja untuk mewakili Kecamatan Rajadesa dan Desa Bojongangsana dipilih secara sengaja untuk mewakili Kecamatan Panumbangan, pertimbangan pemilihan desa-desa tersebut didasarkan pada kepemilikan lahan potensial untuk usahatani jagung, memiliki luas areal tanam terluas dibandingkan dengan desa lainnya dengan areal tanaman dalam satu hamparan serta kebiasaan petani yang melaksanakan usahatani jagung secara kontinu.

2. Sampel tingkat Petani

Dari keempat desa terpilih tersebut diperoleh data sub populasi petani jagung pada masing-masing desa. Data yang diperoleh 


\section{AIMBAR \\ Agribisnis}

ISSN 2460-4321

Volume 1・ Nomor 2・ Januari 2016

hanya berupa data jumlah petani tanpa adanya data mengenai luas kepemilikan lahan pada masing-masing petani di keempat desa tersebut. Berdasarkan data BPP (Balai Penyuluhan Pertanin) dari masing-masing kecamatan diperoleh jumlah sub populasi petani jagung sebagai berikut :

a. Desa Kertamandala Kecamatan Panjalu mempunyai petani jagung sebanyak 268 orang. (BPP Kecamatan Panjalu, 2006)

b. Desa Bojongangsana Kecamatan Panumbangan mempunyai petani jagung sebanyak 402 orang (BPP Kecamatan Panumbangan, 2006)

c. Desa Tanjungjaya Kecamatan Rajadesa mempunyai petani jagung sebanyak 362 orang (BPP Kecamatan Rajadesa, 2006)

d. Desa Sukanegara Kecamatan Padaherang mempunyai petani jagung sebanyak 396 orang (BPP Kecamatan Padaherang, 2006)

3. Penentuan Responden

Pertimbangan yang digunakan dalam menentukan sampel fraction bisa sebesar 10 persen adalah pendapat Nazir (1993) yang menyatakan bahwa untuk populasi yang besar bisa diambil sample fraction yang kecil. Dengan demikian sampel petani dari masing-masing kecamatan tersebut di atas yang akan menjadi responden adalah :

a. Desa Kertamandala Kecamatan Panjalu 27 orang

b. Desa Bojongangsana Kecamatan Panumbangan 40 orang

c. Desa Tanjungjaya Kecamatan Rajadesa 36 orang

d. Desa Sukanegara Kecamatan Padaherang 40 orang

Pemilihan petani responden yang akan diwawancarai sebanyak 143 orang tersebut dilakukan secara acak sederhana (simple random sampling) dari masing-masing desa tersebut.

Data yang dikumpulkan dalam penelitian ini meliputi data primer dan data sekunder. Sedangkan sumber data dalam penelitian ini adalah petani jagung yang ada di desa Kertamandala Kecamatan panjalu dimana pelaksanaan pengumpulan data primer dengan cara peneliti langsung mewawancarai responden dengan menggunakan kuesioner yang berisi pertanyaan yang telah dipersiapkan.
Sedangkan data sekunder adalah data yang diperoleh berdasarkan literatur-literatur dari instansi-instansi yang terkait dengan penelitian ini.

Untuk mengetahui besarnya biaya, penerimaan, pendapatan dan $\mathrm{R} / \mathrm{C}$ usahatani jagung di Kecamatan panjalu Kabupaten Ciamis dianalisis dengan menggunakan rumus sebagai berikut (Abas Tjakrawiralaksana, 1983).

1. Untuk mengetahui Biaya Total (Total Cost) menggunakan rumus :

$$
\mathrm{TC}=\mathrm{TFC}+\mathrm{TVC}
$$

Keterangan :

$\mathrm{TC}=$ Total Cost (Biaya Total)

TFC $=$ Total Fixed Cost (Biaya Tetap Total)

$\mathrm{TVC}=$ Total Variable Cost (Biaya Variabel Total)

2. Penerimaan dihitung dengan rumus sebagai berikut :

$\mathrm{TR}=\mathrm{Y} . \mathrm{Hy}$

Keterangan :

TR = Total Revenue (Penerimaan Total)

$\mathrm{Y}=$ Produk yang dihasilkan

Hy = Harga Satuan

3. Sedangkan untuk mengetahui pendapatan digunakan rumus sebagai berikut :

$\mathrm{P}=\mathrm{TR}-\mathrm{TC}$

Keterangan :

$\mathrm{P}=$ Pendapatan

$\mathrm{TR}=$ Total Revenue (Penerimaan Total)

$\mathrm{TC}=$ Total Cost $($ Biaya Total $)$

4. Untuk mengetahui apakah usahatani tersebut menguntungkan atau merugikan dapat digunakan rumus

$$
\mathrm{R} / \mathrm{C}=\frac{\text { Total Penerimaan }}{\text { Total Biaya }}
$$

Dengan ketentuan bila : R/C > 1, maka usahatani tersebut menguntungkan.

$\mathrm{R} / \mathrm{C}=1$, maka usahatani tersebut impas $\mathrm{R} / \mathrm{C}<1$, maka usahatani tersebut rugi 


\section{Analisa Kelayakan Usahatani Jagung \\ di Kabupaten Ciamis}

AI HUSNUL KHOTIMAH

\section{HASIL DAN PEMBAHASAN}

Usahatani jagung di Kabupaten Ciamis sama halnya dengan usahatani tanaman palawija lainnya seperti kedelai dan kacang tanah sudah mulai pada usahatani komersial. Dalam melaksanakan usaha tani jagung sebagian kecil petani tidak melaksanakan pengolahan tanah (TOT) yang artinya petani langsung menanam biji jagung pada lahan yang tersedia dengan cara di tugal. Sedangkan sebagian besar lainnya, petani melaksanakan pengolahan tanah dalam berusaha tani jagung dengan kedalaman kurang lebih $10 \mathrm{~cm}$. Lahan yang sudah diolah kemudian di tugal dengan kedalaman 3-5 cm, kemudian benih jagung dimasukan ke dalam lubang tanam yang telah di tugal tadi. Biji jagung yang ditanam sebanyak 2-3 biji per lubang tanam, dengan jarak tanam $50 \times 30 \mathrm{~cm}$. Kebutuhan benih rata-rata per hektarnya sebanyak 24, $92 \mathrm{~kg}$. Bila di bandingkan dengan rekomendasi pemerintah penanaman biji jagung per lubang tanam yang dilakukan petani dapat dikatakan belum efektif dan efisien, dimana menurut rekomendasi untuk benih jagung hibrida yang berumur 80 sampai 90 hari cukup di tanam satu biji per lubang tanam.

Pupuk dasar organik diberikan sebelum pengolahan tanah dengan cara menyebarkan dan diratakan pada saat pengolahan tanah. Kebutuhan pupuk organik per hektar dalam satu kali musim tanam di kabupaten Ciamis $3.449,04 \mathrm{~kg}$ per hektar. Bila dibandingkan dengan rekomendasi pemerintah, dalam penggunaan pupuk dasar organik masih jauh di bawah yang di rekomendasikan. Pemupukan untuk pupuk organik dilakukan dua kali per musim tanam, yaitu pemupukan pertama dilaksanakan 7 setelah tanam, dan pemupukan susulan dilaksanakan 35 hari setelah tanam. Rata-rata kebutuhan pupuk per hektar dalam satu kali musim tanam adalah $226,98 \mathrm{~kg}$ urea, 94,33 kg SP 36 atau TSP, serta 50,73 kg KCL.

Sebagian besar petani melakukan penyulaman untuk tanaman yang mati atau tidak tumbuh kurang dari 7 hari setelah tanam, sedangkan penjarangan dilaksanakan setelah 10 sampai 18 hari setelah tanam dengan menggunakan pisau atau gunting.

Penggunaan pestisida merupakan salah satu cara penanggulangan hama dan penyakit yang dapat dilakukan petani. Rata-rata kebutuhan pestisida pada usaha tani jagung per hektar dalam satu kali musim tanam yang biasa dilakukan petani di Kabupaten Ciamis adalah sebanyak 2,29 liter.

Pelaksanaan pemanenan dilakukan setelah jagung matang mati dengan ciri-ciri seluruh bagian tanaman telah mengering, serta biji keras benar dan beratnya menurun dengan kadar air 17-18 persen. Tujuan pelaksanaan panen seperti ini adalah karena tuntutan pasar dimana sebagian besar jagung yang dihasilkan petani di Kabupaten Ciamis merupakan pasokan pada perusahaan pakan ternak Tanjung Mulya, sehingga jagung yang dihasilkan dituntut matang mati.

\section{Mengukur Kelayakan}

Mengukur tingkat kelayakan usaha tani jagung di Kabupaten Ciamis pada penelitian ini menggunakan analisis pendapatan dan imbangan penerimaan dengan biaya yang dikeluarkan (R/C) dengan rumus sebagai berikut:

$$
\mathbf{R} / \mathbf{C}=\frac{\text { Penerimaan Total }}{\text { Biaya Total }}
$$

Biaya total pada usaha tani jagung di Kabupaten Ciamis sebesar Rp. 3.636.797,33. Dan biaya tersebut sebagian besarnya dipergunakan untuk biaya variabel sebesar Rp.3.310.463,75 (91,032\%) dan sebagian lagi dipergunakan untuk biaya tetap sebesar Rp.326.333,58 (8,97\%).

Biaya variabel yang terbesar dipergunakan untuk biaya tenaga kerja sebesar Rp.1.666,596,13, dan sebagiannya lagi dipergunakan untuk pembelian benih, pupuk kandang, urea, TSP dan KCL, serta untuk pembelian pestisida. 


\section{AIMBAR \\ Agribisnis \\ ISSN 2460-4321}

Volume 1・ Nomor $2 \cdot$ Januari 2016

Tabel 3. Biaya Produksi Usahatani Jagung per Hektar per musim Tanam di Kabupaten Ciamis Tahun 2007

\begin{tabular}{|l|l|r|r|}
\hline No & \multicolumn{1}{|c|}{ Komponen Biaya } & Jumlah Biaya (Rupiah) & Persentase (\%) \\
\hline 1. & Biaya Tetap & $40.885,41$ & 1,12 \\
& a. Penyusutan Alat & $16.005,77$ & 0,44 \\
& b. Pajak Lahan & $269.392,40$ & 7,41 \\
& c. Bunga Modal & $326.333,58$ & 8,97 \\
2. & Biaya Variabel & & 15,76 \\
& a. Benih & $573.226,18$ & \\
& b. Pupuk & & 8,74 \\
& - Pupuk kandang & $172.451,88$ & 4,74 \\
& - Pupuk Urea & $317.777,02$ & 4,02 \\
& - Pupuk KCL & $91.321,57$ & 2,51 \\
& - Pupuk TSP & $146.204,74$ & 9,43 \\
& c. Pestisida & $342.886,23$ & 45,83 \\
& d. Tenaga Kerja & $1.666 .596,13$ & 91,03 \\
\hline 3. & Biaya Variabel Total & $3.310 .463,75$ & 100,00 \\
\hline
\end{tabular}

Adapun harga jual jagung di Kabupaten Ciamis pada saat penelitian sangat bervariatif tergantung pada daerah masing-masing berkisar antara Rp. 1.150,00 sampai Rp. 1.400,00 per kilogram. Untuk mengetahui besarnya biaya total, rata-rata produksi, penerimaan dan pendapatan per hektar per musim tanam dari usahatani jagung di Kabupaten Ciamis dapat dilihat pada Tabel 2.

Tabel 4. Rata-rata Biaya Total, Hasil Produksi Penerimaan dan Pendapatan per Hektar per Musim Tanam pada Usahatani Jagung di Kabupaten Ciamis

\begin{tabular}{|c|l|c|r|}
\hline No & \multicolumn{1}{|c|}{ Komponen } & Satuan & \multicolumn{1}{|c|}{ Nilai } \\
\hline 1. & Biaya Total & $\mathrm{Rp} / \mathrm{Ha}$ & $3.636 .797,33$ \\
2. & Produksi Total & $\mathrm{Kg} / \mathrm{Ha}$ & $6.604,31$ \\
3. & Penerimaan & $\mathrm{Rp}$ & $8.076 .614,63$ \\
4. & Pendapatan & $\mathrm{Rp}$ & $4.439 .817,30$ \\
\hline
\end{tabular}

Nilai R/C usahatani jagung di Kabupaten Ciamis adalah sebagai berikut :

$$
\begin{gathered}
\mathrm{R} / \mathrm{C}=\frac{8.076 .617,63}{3.636 .797,33} \\
=2,22
\end{gathered}
$$

Nilai R/C 2,22 artinya setiap Rp.1,00 biaya yang dikeluarkan, menghasilkan penerimaan sebesar 2,22 sehingga pendapatannya sebesar Rp. 1,22. Dengan demikian usahatani jagung di Kabupaten Ciamis menguntungkan.

\section{PENUTUP}

\section{Simpulan}

Berdasarkan hasil dan pembahasan, maka dapat ditarik simpulan sebagai berikut :

1) Usahatani jagung di Kabupaten Ciamis sudah mengarah pada usahatani komersial, dengan teknik budidaya konvensional. Dalam pelaksanaannya agribisnis jagung di Kabupaten Ciamis dilaksanakan secara terpadu dengan budidaya ternak. Proses produksi dimulai dari penyiapan lahan, penanaman, pemeliharaan sampai dengan pasca panen. Nilai R/C 2,22 dengan demikian usahatani jagung di Kabupaten Ciamis menguntungkan.

2) Sebagian besar jagung dihasilkan petani merupakan pasokan untuk industri pakan ternak dan sebagian lainnya digunakan untuk industri olahan makanan, jagung yang dijual petani adalah jagung pipil kering dengan kadar air 17 sampai 18 persen. 


\section{Analisa Kelayakan Usahatani Jagung \\ di Kabupaten Ciamis}

AI HUSNUL KHOTIMAH

\section{Saran}

Berdasarkan simpulan di atas, dapat dibuat beberapa kesimpulan sebagai berikut:

1) Usahatani jagung yang dilaksanakan petani harus dipertahankan dan bahkan ditingkatkan, karena dari usahatani tersebut sudah diperoleh nilai keuntungan.

2) Harus diupayakan adanya sistem kerjasama yang saling menguntungkan antara petani dengan industri pakan ternak. Industri pakan ternak jangan hanya menampung hasil produksi saja, kalau dimungkinkan dengan membiayai usahatani yang dilaksanakan oleh petani.

\section{DAFTAR PUSTAKA}

Aksi Agraria Kanisius. 1993. Teknik Bercocok Tanam Jagung. Kanisius. Yogyakarta

Abas Tjakrawiralaksana. 1983. Usahatani. Departemen Ilmu-ilmu Sosial Ekonomi Pertanian Fakultas Pertanian Institut Pertanian Bogor. Bogor.

Balai Penyuluh Pertanian Kecamatan Padaherang. 2006. Program dan Programa Penyuluh Pertanian BPP Kecamatan Padaherang Kabupaten Ciamis. Ciamis.

Balai Penyuluh Pertanian Kecamatan Panumbangan. 2006. Program dan Programa Penyuluh Pertanian BPP Kecamatan Panumbangan Kabupaten Ciamis. Ciamis.

Balai Penyuluh Pertanian Kecamatan Panjalu. 2006. Program dan Programa Penyuluh Pertanian BPP Kecamatan Panjalu Kabupaten Ciamis. Ciamis.

Balai Penyuluh Pertanian Kecamatan Rajadesa. 2006. Program dan Programa Penyuluh Pertanian BPP Kecamatan Rajadesa Kabupaten Ciamis. Ciamis.

Baharsyah, S. 1996. Sektor Pertanian dalam ekonomi yang mengalami transformasi industrial. Bahan pembahasan dengan civitas academica IPB. Bogor 23 September 1996. (tidak dipublikasikan).

Dinas Pertanian Tanaman Pangan Provinsi Jawa Barat. Pedoman Umum Agribisnis Hortikultura. 2004.

Hernanto. 1991. Ilmu Usahatani. Penebar Swadaya. Jakarta.

Kasryno, F dan Suryana. 1992. Country Paper Indonesia, dalam APO Seminar on Struktural Adjusment of Agriculture in
Asian and The Pasific. Asian Productivity Organization. Tokyo. Japan.

Mubyarto. 1989. Pengantar Ekonomi Pertanian. LP3S. Jakarta.

Nazir. 1988. Metode Penelitian. Ghalia Indonesia. Jakarta.

Sarasutha. 2002. Kinerja Usahatani dan Pemasaran Jagung di Sentra Produksi. Jurnal Litbang Pertanian. Jakarta.

Samuel, Musyafak, A., dan Sahari, D. 1999. Gelar Teknologi Jagung Bisma di Lahan Kering, Kabupaten Bengkayang Kalimantan Barat. Loka Pengkajian Teknologi Pertanian. Pontianak.

Soekartawi. 1993. Resiko dan Ketidakpastian dalam Agribisnis Teori dan Aplikasi. PT Raja Grafindo Persada, Jakarta.

Steidelmeier. 1987. The Paradox of Proverty, A Reappracial of Economic Development Policy. Ballinger Publishing Co, Cambridge.

Teken, I.B. dan Asnawi, S. 1997. Teori Ekonomi Makro. Departemen Ilmu-ilmu Sosial Ekonomi Fakultas Pertanian. Institut Pertanian Bogor. Bogor. 


\section{AIMBAR Agribisnis}

ISSN 2460-4321

Volume 1・Nomor 2・Januari 2016 